\title{
Pengaruh Media Pembelajaran Digital Animasi dan Kepercayaan Diri terhadap Hasil Belajar Pendidikan Agama Islam Anak
}

\author{
Nur Qomariah Panjaitan ${ }^{\otimes_{1}}$, Elindra Yetti ${ }^{2}$, Yuliani Nurani ${ }^{3}$ \\ Pendidikan Anak Usia Dini, Universitas Negeri Jakarta \\ DOI: $10.31004 /$ obsesi.v4i2.404
}

\begin{abstract}
Abstrak
Penelitian ini bertujuan untuk mengetahui pengaruh media pembelajaran digital animasi dan kepercayaan diri terhadap hasil belajar Pendidikan Agama Islam. Populasi dalam penelitian ini adalah siswa kelas 2 SD di kota Medan dengan sampel 32 anak dalam kelompok eksperimen dan 32 anak dalam kelompok kontrol. Sampel diambil dengan teknik cluster sampling. Data dikumpulkan melalui tes yang telah divalidasi. Teknik analisis data menggunakan uji varians (ANAVA) dua jalur serta pengujian tukey. Sebelum uji hipotesis dilakukan terlebih dahulu dilakukan uji normalitas dan uji homogenitas. Hasil analisis data menunjukkan bahwa terdapat interaksi media pembelajaran digital dan kepercayaan diri terhadap hasil belajar Pendidikan Agama Islam dengan hasil analisis varians nilai $\mathrm{F}$ hitung $=4,97>\mathrm{F}$ tabel $=3,99$ pada taraf signifikan $=0,05$.
\end{abstract}

Kata Kunci: media pembelajaran digital animasi; kepercayaan diri; hasil belajar; pendidikan agama islam.

\begin{abstract}
This study aims to determine the effect of digital animation learning media and selfconfidence on learning outcomes of Islamic Religious Education. The population in this study was grade 2 elementary school students in the city of Medan with a sample of 32 children in the experimental group and 32 children in the control group. Samples were taken by cluster sampling technique. Data is collected through validated tests. Data analysis techniques using the two-way variance test (ANAVA) and tukey testing. Before testing the hypothesis is done first, it is tested for normality and homogeneity. The results of data analysis indicate that there is an interaction between digital learning media and selfconfidence in the learning outcomes of Islamic Religious Education with the results of analysis of variance $\mathrm{F}$ value $=4.97>\mathrm{F}$ table $=3.99$ at a significant level $=0.05$
\end{abstract}

Keywords: digital animation learning media; self-confidence;learning outcomes; islamic religious education.

Copyright (c) 2020 Nur Qomariah Panjaitan, Elindra Yetti, Yuliani Nurani

$\triangle$ Corresponding author :

Email Address : nurqomariahpanjaitan_paud17s2@mahasiswa.unj.ac.id (Jakarta, Indonesia)

Received 19 December 2019, Accepted 7 January 2019, Published x January 2020

\section{PENDAHULUAN}

Materi Pendidikan Agama Islam pada jenjang Pendidikan Dasar diintegrasikan pada bidang studi antara lain pada mata pelajaran Pendidikan Kewarganegaraan (PPKn). Pendidikan Agama Islam di Sekolah Dasar bertujuan untuk menumbuhkan dan meningkatkan keimanan melalui pemberian dan pemupukan pengetahuan, penghayatan, serta pengalaman peserta didik tentang agama Islam sehingga menjadi manusia muslim 
yang terus berkembang dalam hal keimanan, ketakwaannya kepada Tuhan Yang Maha Esa (Lubis, 2017). Pendidikan Agama Islam diberikan dengan mengikuti tuntunan bahwa agama diajarkan kepada manusia untuk mewujudkan manusia yang bertakwa kepada Allah Swt., berakhlak mulia, serta bertujuan untuk menghasilkan manusia yang jujur, adil, berbudi pekerti, etis, saling menghargai, disiplin, harmonis dan produktif, baik secara personal maupun sosial.

Menurut Undang-Undang Dasar 1945 pasal 31 ayat 3 dan Sistem Pendidikan Nasional nomor 20 tahun 2003 yang menyatakan bahwa pemerintah mengusahakan dan menyelenggarakan satu sistem pendidikan nasional, yang meningkatkan keimanan dan ketakwaan serta akhlak mulia agar dalam rangka mencerdaskan kehidupan bangsa agar menjadi manusia yang beriman dan bertaqwa kepada Tuhan Yang Maha Esa, berakhlak mulia, sehat, berilmu, cakap, kreatif, mandiri, dan menjadi warga negara yang demokratis serta bertanggung jawab (Latif, Zukhairina, Zubaidah, \& Afandi, 2016). Dalam hal untuk mengembangkan potensi peserta didik agar menjadi manusia yang beriman dan bertakwa kepada Tuhan Yang Maha Esa salah satunya yaitu dengan mengajarkan pelajaran Pendidikan Agama Islam di Sekolah Dasar.

Anak harus ditanamkan nilai nilai Agama Islam agar anak membiasakan diri untuk berbuat baik, melakukan tindakan dan pengambilan keputusan dalam hidupnya didasarkan pada nilai-nilai Agama Islam yang diimaninya sampai dewasa nanti. Dalam pembelajaran Agama Islam, guru dapat membelajarkan melalui pembiasaan dengan menggunakan perintah, contoh atau tauladan dan pengalaman khusus juga menggunakan hukum-hukum dan ganjaran agar anak memperoleh sikap-sikap dan kebiasaan-kebiasaan perbuatan baru yang lebih tepat dan positif dalam arti selaras dengan kebutuhan ruang dan waktu (kontesktual) (Tohirin, 2005).

Penelitian yang dilakukan Islahuddin (2015) yang menyatakan bahwa pada saat menyampaikan materi pelajaran Pendidikan Agama Islam, guru masih menggunakan metode ceramah dengan bantuan papan tulis dan gambar sederhana. Selanjutnya, nilai rata rata mata pelajaran Pendidikan Agama Islam siswa kelas 2 SD sebanyak 70\% masih di bawah KKM. Kemudian, dalam mata pelajaran Pendidikan Agama Islam, guru masih jarang menggunakan dan belum memanfaatkan teknologi dalam pembelajaran karena menyebabkan masalah dalam pemahaman anak. Sesuai dengan penelitian yang dilakukan oleh Mahfudzah, K, \& Tanjung (2018) yang menyatakan pelajaran Agama Islam dipandang kurang menarik sehingga timbul masalah dalam pemahaman siswa karena jarang menggunakan media. Kemudian, masih terbatasnya penggunaan media animasi dalam proses pembelajaran mata pelajaran Pendidikan Agama Islam. Hal ini sesuai dengan penelitian yang dilakukan Sukiyasa \& Sukoco (2013) yang menyatakan masih terbatasnya penggunaan media animasi karena memerlukan keahlian khusus untuk membuat media tersebut.

Selanjutnya, masih rendahnya minat belajar anak karena guru hanya terpaku pada buku teks sebagai satu-satunya sumber belajar. Hal ini sesuai dengan penelitian dilakukan oleh Handayani, Yetri, \& Putra, (2018) menyatakan bahwa media pembelajaran yang masih terbatas pada buku yang penyajian materinya padat dan tampilannya tidak menarik serta banyaknya soal-soal dan tugas-tugas yang diberikan pendidik sehingga membuat peserta didik bosan untuk belajar.

Pada mata pelajaran Pendidikan Agama Islam terkesan lebih banyak terfokus pada teori. Hal ini sejalan dengan penelitian yang dilakukan oleh Fua \& Sartiwi (2015) dan Kasan (2018) juga menyatakan bahwa pelajaran tentang Pendidikan Agama Islam terkesan lebih banyak terfokus pada masalah teoritis, dalam ranah metodologi pembelajaran masih terkesan konvensional dan jarang adanya inovasi. Terlihat jelas bahwa media pembelajaran untuk mata pelajaran Pendidikan Agama Islam masih memakai buku teks sebagai satu satunya sumber belajar dan jarang adanya inovasi yang membuat minat belajar anak rendah sehingga mempengaruhi hasil belajar anak.

Berdasarkan paparan di atas, maka penggunaan media animasi sesuai dengan tahap perkembangan anak dalam pembelajaran Pendidikan Agama Islam. Di mana tampilan media pembelajaran digital animasi dapat mendukung pembelajaran yang aktif, kreatif, efektif dan menyenangkan. 


\section{METODOLOGI}

Penelitian ini dilakukan dengan menggunakan metode eksperimen dengan membandingkan media pembelajaran digital animasi dan media pembelajaran digital storytelling dengan variabel moderatornya kepercayaan diri.

Desain yang digunakan pada penelitian ini adalah rancangan desain treatment by level $2 \times 2$. Adapun desain penelitian ini terbagi atas tiga variabel dengan rincian variabel bebas dibentuk menjadi dua bagian yaitu variabel perlakuan menggunakan media pembelajaran digital animasi dan media pembelajaran digital storytelling. Sementara kepercayaan diri sebagai variabel moderatoryang terdiri dari kepercayaan diri tinggi dan kepercayaan diri rendah, sedangkan variabel terikatnya adalah hasil belajar Pendidikan Agama Islam.

Penelitian ini akan dilaksanakan di 2 sekolah yaitu Sekolah Dasar Negeri 064037 di Kelurahan Bandar Selamat berjumlah 59 anak dan Sekolah Dasar Negeri 060913 Kelurahan Bantan yang berjumlah 58 anak. Pemilihan tempat penelitian berdasarkan letak geografis yang berada didaerah yang sama yaitu di Kecamatan Medan Tembung. Kisi-kisi instrumen terbagi menjadi dua, yaitu kisi-kisi instrumen non tes kepercayaan diri dan kisi kisi instrumen tes hasil belajar Pendidikan Agama Islam.

Tabel 1. Kisi-Kisi Instrumen Kepercayaan Diri

\begin{tabular}{|c|c|c|c|c|}
\hline No & Aspek & Indikator & $\begin{array}{l}\text { Nomor } \\
\text { Butir }\end{array}$ & Jumlah \\
\hline \multirow[t]{3}{*}{1.} & Penilaian & a. Mempercayai kemampuan diri sendiri & $1,10,19$ & 3 \\
\hline & terhadap & b. Membandingkan diri dengan orang lain & $2,11,20$ & 3 \\
\hline & diri sendiri & c. Memahami tindakan & 3,12 & 2 \\
\hline \multirow[t]{2}{*}{2.} & Optimis & a. Berpandangan baik tentang diri & 4,13 & 2 \\
\hline & & b. Berpandangan baik tentang kemampuan & 5,14 & 2 \\
\hline \multirow[t]{2}{*}{3.} & Keberanian & $\begin{array}{l}\text { a. Berani mengungkapkan gagasan dan } \\
\text { perasaan }\end{array}$ & 6,15 & 2 \\
\hline & & b. Mampu berinteraksi dengan baik & 7,16 & 2 \\
\hline \multirow[t]{3}{*}{4} & Bertanggun & a. Kesediaan terhadap sesuatu & 8,17 & 2 \\
\hline & g Jawab & b. Siap menerima konsekuensi & 9,18 & 2 \\
\hline & & TOTAL & \multicolumn{2}{|c|}{20} \\
\hline
\end{tabular}

Tabel 2. Kisi-Kisi Instrumen Hasil Belajar Pendidikan Agama Islam

\begin{tabular}{|c|c|c|c|c|}
\hline No & $\begin{array}{c}\text { Kompetensi } \\
\text { Dasar }\end{array}$ & Materi & Indikator & Butir soal \\
\hline \multirow[t]{5}{*}{1.} & $\begin{array}{l}\text { 3.4.Memahami hadits } \\
\text { yang terkait dengan }\end{array}$ & $\begin{array}{l}\text { Hidup } \\
\text { Bersih }\end{array}$ & $\begin{array}{l}\text { Menyebutkan perilaku hidup } \\
\text { bersih dan sehat }\end{array}$ & $1,11,21$ \\
\hline & $\begin{array}{l}\text { perilaku hidup bersih } \\
\text { dan sehat }\end{array}$ & $\begin{array}{l}\text { dan } \\
\text { Sehat }\end{array}$ & $\begin{array}{l}\text { Menyebutkan hadits tentang } \\
\text { kebersihan }\end{array}$ & $2,12,22$ \\
\hline & & & $\begin{array}{l}\text { Menyebutkan contoh perilaku } \\
\text { peduli dengan lingkungan }\end{array}$ & $3,13,23$ \\
\hline & & & $\begin{array}{l}\text { Menjelaskan tata cara makan } \\
\text { yang benar }\end{array}$ & $4,14,24$ \\
\hline & & & $\begin{array}{l}\text { Menyebutkan do'a makan } \\
\text { sebelum dan sesudah makan }\end{array}$ & $5,15,25$ \\
\hline \multirow[t]{6}{*}{2.} & $\begin{array}{l}\text { 3.9.Memahami } \\
\text { do'a sebelum }\end{array}$ & $\begin{array}{l}\text { Ayo } \\
\text { Berwudh }\end{array}$ & $\begin{array}{l}\text { Menyebutkan niat wudhu' dan } \\
\text { do'a setelah berwudhu }\end{array}$ & 6,16 \\
\hline & $\begin{array}{l}\text { dan sesudah } \\
\text { wudhu }\end{array}$ & $\mathrm{u}$ & $\begin{array}{l}\text { Mampu menyebutkan syarat } \\
\text { wudhu' }\end{array}$ & 7,17 \\
\hline & & & Menjelaskan rukun wudhu & 8,18 \\
\hline & & & Menyebutkan Sunnah wudhu & 9,19 \\
\hline & & & $\begin{array}{l}\text { Menjelaskan hal yang } \\
\text { membatalkan wudhu }\end{array}$ & 10,20 \\
\hline & \multicolumn{2}{|c|}{ TOTAL } & 25 & \\
\hline
\end{tabular}

\section{HASIL DAN PEMBAHASAN}

Data penelitian ini terdiri dari tiga jenis variabel yaitu variabel bebas atau perlakuan, variabel atribut dan terikat. Variabel bebas atau perlakuan dalam peneitian ini adalah media 
pembelajaran digital animasi dan media pembelajaran digital storytelling. Variabel atribut dalam penelitian ini adalah kepercayaan diri tinggi dan kepercayaan diri rendah, sedangkan variabel terikatnya adalah hasil belajar pada mata pelajaran Pendidikan Agama Islam kelas 2 SD yang diperoleh anak setelah belajar dengan proses pembelajaran.

Setelah belajar dengan proses pembelajaran yang menerapkan media pembelajaran digital animasi dan media pembelajaran digital storytelling maka akan diperoleh hasil belajar anak berupa skor. Hasil tersebut berupa kumpulan data yang didapat setelah masingmasing kelompok diberikan perlakuan, selanjutnya akan digunakan sebagai bahan untuk analisis.

Deskripsi data penelitian dari ketiga variabel tersebut akan dinyatakan dalam bentuk ukuran pemusatan data, antara lain : a) rata-rata (mean); b) simpangan baku (standar deviasi); (c) nilai tengah (median); d) frekuensi terbanyak yang muncul (mode). Sebaran data yang akan dideskripsikan dalam tabel berbentuk rentang rekor skor (range) dan frekuensi, selanjutnya akan disajikan dalam bentuk tabel distribusi frekuensi dan histogram. Adapun kumpulan data analisis tendensi sentral hasil belajar Pendidikan Agama Islam yaitu seperti pada tabel berikut ini :

Tabel 3. Deskripsi Data Analisis Tendensi Sentral

\begin{tabular}{cll}
\hline & $\begin{array}{c}\text { Eksperimen (Media } \\
\text { Pembelajaran Digital Animasi) } \\
\text { A1 }\end{array}$ & $\begin{array}{l}\text { Kontrol (Media Pembelajaran } \\
\text { Digital Storytelling) A2 }\end{array}$ \\
\hline $\begin{array}{c}\text { Kepercayaan diri } \\
\text { tinggi (B1) }\end{array}$ & $\begin{array}{l}\text { Mean }=16 \\
\text { Median }=83,06\end{array}$ & $\begin{array}{l}\text { Mean }=16 \\
=77,06\end{array}$ \\
& Modus $=81$ & Median $=77$ \\
& SD $=2,26$ & Modus $=81$ \\
Kepercayaan diri & $\mathrm{N}=16$ & SD $=1,76$ \\
rendah (B2) & Mean $=76,06$ & $\mathrm{~N}=16$ \\
& Median $=76$ & Mean $=72$ \\
& Modus $=75$ & Median $=72$ \\
& SD $=2,23$ & Modus $=73$ \\
& & SD $=1,43$ \\
\hline
\end{tabular}

\section{Uji Normalitas}

Tabel 4. Rangkuman Hasil Uji Normalitas Keseluruhan Data

\begin{tabular}{ccccc}
\hline Kelompok & $\mathbf{N}$ & $\mathbf{L}_{\text {hitung }}$ & $\mathbf{L}_{\text {tabel }}$ & Kesimpulan \\
\hline $\mathrm{A}_{1}$ & 32 & 0.0837 & 0.1566 & Normal \\
$\mathrm{A}_{2}$ & 32 & 0.0864 & 0.1566 & Normal \\
$\mathrm{B}_{1}$ & 32 & 0.1385 & 0.1566 & Normal \\
$\mathrm{B}_{2}$ & 32 & 0.1341 & 0.1566 & Normal \\
$\mathrm{A}_{1} \mathrm{~B}_{1}$ & 16 & 0.1805 & 0.2128 & Normal \\
$\mathrm{A}_{1} \mathrm{~B}_{2}$ & 16 & 0.1202 & 0.2128 & Normal \\
$\mathrm{A}_{2} \mathrm{~B}_{1}$ & 16 & 0.2016 & 0.2128 & Normal \\
$\mathrm{A}_{2} \mathrm{~B}_{2}$ & 16 & 0.1453 & 0.2128 & Normal \\
\hline
\end{tabular}

Hasil perhitungan uji normalitas pada semua data kelompok penelitian diketahui bahwa L hitung untuk semua kelompok lebih kecil dari pada L tabel, ini berarti menunjukkan nahwa semua kelompok penelitian berdistribusi normal. Hasil perhitungan uji coba normalitas dengan uji Liliefors secara keseluruhan. 
Tabel 5. Rangkuman Hasil Uji Homogenitas Varians Kelompok Data

\begin{tabular}{cccl}
\hline Kelompok & $\mathbf{X}^{2}$ hitung & $\begin{array}{l}\mathbf{X}^{2} \text { tabe } \\
\mathbf{1}\end{array}$ & $\begin{array}{l}\text { Kesimpula } \\
\mathbf{n}\end{array}$ \\
\hline $\mathrm{A}_{1}$ dan $\mathrm{A}_{2}$ & 1.583 & 3,841 & Homogen \\
$\mathrm{B}_{1}$ dan $\mathrm{B}_{2}$ & 0.850 & 3,841 & Homogen \\
$\mathrm{A}_{1} \mathrm{~B}_{1}, \mathrm{~A}_{1} \mathrm{~B}_{2}, \mathrm{~A}_{2}$ & \multirow{2}{*}{1.477} & 7.815 & Homogen \\
$\mathrm{B}_{1}, \mathrm{~A}_{2} \mathrm{~B}_{2}$ & & & \\
\hline
\end{tabular}

Hasil perhitungan uji homogenitas dari ketiga kelompok data diperoleh $X^{2}$ hitung lebih kecil dari $X^{2}$ tabel berdasarkan taraf $a=0,05$. Maka dapat disimpulkan keempat kelompok data mempunyai varians yang sama besar, maka kelompok data tersebut bersifat homogeny. Hasil pengujian normalitas dan homogenitas dari data tersebut menunjukkan bahwa kelompok-kelompok data pada penelitian ini berasal dari populasi yang berdistribusi normal dan memiliki varians data yang homogeny. Berdasarkan hal tersebut maka pernyaratan untuk melakukan pengujian hipotesis dengan analisis varians (ANAVA).

Tabel 6. Rangkuman Hasil Perhitungan ANAVA Dua Jalur

\begin{tabular}{lccccc}
\hline Sumber Varians & JK & Db & RJK & F hit & $\begin{array}{c}\text { F tab } \\
\mathrm{a}=0,05\end{array}$ \\
\hline Antar A & 400 & 1 & 400 & 104,46 & 3,99 \\
Antar B & 576 & 1 & 576 & 150,42 & 3,99 \\
Interaksi AXB & 16 & 1 & 16 & 4,24 & 3,99 \\
Dalam & 229,75 & 61 & 3,76 & & \\
Total & 1221,75 & 64 & & & \\
\hline
\end{tabular}

Dari hasil analisa diketahui nilai $\mathrm{F}_{\mathrm{OA}}=104,46$. Dari tabel daftar-H pada $\mathrm{db}(\mathrm{A}) / \mathrm{db}(\mathrm{D})$ $=1 / 61$, dan $\mathrm{a}=0,05$ diketahui nilai Ftabel $=3,99$ karena $\mathrm{F}_{(\mathrm{OA})}=104,46$ atau Ho ditolak, jadi terdapat perbedaan rata-rata hasil belajar Pendidikan Agama Islam antara anak yang belajar menggunakan media pembelajaran digital animasi dan media pembelajaran digital storytelling.

Dari hasil analisa diketahui nilai $\mathrm{F}_{\mathrm{OB}}=150,42$ Dari tabel daftar- $\mathrm{H}$ pada $\mathrm{db}(\mathrm{A}) / \mathrm{db}(\mathrm{D})$ $=1 / 61$, dan $\alpha=0,05$ diketahui nilai Ftabel $=3,99$ karena $\mathrm{F}_{(\mathrm{OA})}=150,42$ atau Ho ditolak, jadi terdapat perbedaan rata-rata hasil belajar Pendidikan Agama Islam antara anak yang memiliki kepercayaan diri tinggi dan anak yang memiliki kepercayaan diri rendah.

Dari hasil analisis diketahui nilai $\mathrm{F}_{(\mathrm{OAB})}=4,24$. Dari tabel daftar-H pada $\mathrm{db}(\mathrm{a}) / \mathrm{db}(\mathrm{D})$ $=1 / 61$, dan $\alpha=0,05$ diketahui nilai $\mathrm{F}$ tabel $=3,99$ karena $\mathrm{F}_{(\mathrm{OAB})}=4,24$ atau Ho ditolak, jadi terdapat pengaruh interaksi antara media pembelajaran digital dan kepercayaan diri terhadap hasil belajar Pendidikan Agama Islam sesuai dengan tinggi rendahnya kepercayaan diri anak.

\section{Uji Lanjutan Tukey}

Tabel 7. Hasil Perhitungan Lanjutan Uji Tukey

\begin{tabular}{|c|c|c|c|c|}
\hline Kelompok & $\mathbf{N}$ & $\mathbf{Q}_{\text {hitung }}$ & $\begin{array}{c}\text { Q } \\
(\mathbf{a}=\mathbf{0 , 0 5})\end{array}$ & Kesimpulan \\
\hline $\mathrm{A}_{1} \mathrm{~B}_{1}$ dan $\mathrm{A}_{2} \mathrm{~B}_{1}$ & 16 & 12,36 & 4.05 & Signifikan \\
\hline $\mathrm{A}_{1} \mathrm{~B}_{2}$ dan $\mathrm{A}_{2} \mathrm{~B}_{2}$ & 16 & 8,24 & 4.05 & Signifikan \\
\hline
\end{tabular}

Dari hasil analisis diketahui bahwa nilai Qhitung A1B1 - A2B1 $=12,36$. Dari tabel Critical Value Of $Q$ ( TUKEY) dengan $\alpha=0,05, \mathrm{k}=4$ dan $\mathrm{n}=16$ diketahui nilai Qtabel $=4,05$. Karena Qhitung A1B1-A2B1 $=12,36>$ Qtabel $=4,05$ atau Ho ditolak, maka hasil belajar Pendidikan Agama Islam anak yang belajar menggunakan media pembelajaran digital animasi yang memiliki kepercayaan diri tinggi lebih tinggi daripada anak yang belajar menggunakan media pembelajaran digital storytelling yang memiliki kepercayaan diri tinggi.

Dari hasil analisis diketahui bahwa nilai Qhitung A1B2 - A2B2 $=8,26$. Dari tabel Critical Value Of Q ( TUKEY) dengan $\mathrm{a}=0,05, \mathrm{k}=4$ dan $\mathrm{n}=14$ diketahui nilai Qtabel $=4,05$. Karena Qhitung A1B2-A2B2 $=8,26>$ Qtabel $=4,05$ atau Ho ditolak, maka hasil belajar Pendidikan Agama Islam anak yang belajar menggunakan media pembelajaran digital 
animasi yang memiliki kepercayaan diri rendah lebih tinggi daripada anak yang belajar menggunakan media pembelajaran digital storytelling yang memiliki kepercayaan diri rendah.

\section{Perbedaan Hasil Belajar Pendidikan Agama Islam antara kelompok anak yang menggunakan Media Pembelajaran Digital Animasi dan kelompok anak yang menggunakan Media Pembelajaran Digital Storytelling}

Dalam kegiatan belajar mengajar pada dasarnya harus dilakukan dengan baik mulai dari cara penyampaian materi, metode dan media pembelajaran yang digunakan guru agar menarik dan menyenangkan bagi anak. Dalam penelitian ini memberikan treatment menggunakan media pembelajaran digital pada mata pelajaran Pendidikan Agama Islam untuk melihat hasil belajar Pendidikan Agama Islam. Media pembelajaran digital yang digunakan dalam penelitian ini adalah media pembelajaran digital animasi dan media pembelajaran Digital Storytelling.

Pelajaran yang dibuat ke visualisasi ke dalam bentuk gambar animasi lebih bermakna dan menarik, lebih mudah diterima, dipahami, lebih dapat memotivasi (Sukiyasa \& Sukoco, 2013). Selanjutnya, hasil belajar siswa menggunakan pembelajaran kooperatif yang diintegrasikan dengan media animasi komputer lebih baik secara signifikan (Irham, 2018). Beberapa pendapat di atas menunjukkan bahwa dengan menggunakan media pembelajaran digital animasi dapat membangkitkan motivasi, daya kreativitas dan semangat belajar siswa agar mencapai hasil belajar yang memuaskan.Media pembelajaran digital animasi memudahkan guru dalam menyampaikan materi mata Pelajaran Agama Islam sehingga anak akan lebih cepat mengerti dan mudah menarik minat anak-anak. Media pembelajaran digital animasi mengandung unsur gambar yang dinamis, warna, musik dan teks sehingga membuat anak menjadi tertarik, termotivasi dan semangat dalam belajar. Dengan adanya minat, ketertarikan, motivasi dan semangat belajar pada siswa dengan menggunakan media pembelajaran digital animasi akanmembuat siswa menjadi percaya diri dalam menjawab soal-soal sehingga mempengaruhi hasil belajar anak dalam mata pelajaran Pendidikan Agama Islam.

Kemudian beberapa hasil penelitian menunjukkan bahwa media pembelajaran Digital Storytelling juga dapat meningkatkan hasil belajar siswa dan terbukti efektif menunjang proses pembelajaran siswa(Prananta, Setyosari, \& Santoso, 2017). Media pembelajaran Digital Storytellingdapat meningkatkan motivasi siswa secara efektif, kompetensi masalah dan pencapaian hasil belajar (Hung, Hwang, \& Huang, 2012). Digital storytelling mengandung unsur gambar yang statis, warna, musik dan suara sehingga membuat siswa juga tertarik dan termotivasi. Dengan adanya ketertarikan dan motivasi siswa terhadap media pembelajaran yang digunakan guru, akan mempengaruhi hasil belajar siswa dalam mata pelajaran Pendidikan Agama Islam.

Dalam penelitian ini terlihat perbedaan hasil belajar Pendidikan Agama Islam kelas 2 SD dengan anak yang belajar menggunakan media pembelajaran digital animasi lebih tinggi daripada anak yang belajar menggunakan media pembelajaran digital storytelling. Pada kelas eksperimen yang menggunakan media pembelajaran digital animasi yang mengandung unsur gambar dinamis, warna, musik dan teks, kemudian guru menampilkan video animasi, lalu guru membentuk beberapa kelompok untuk peserta didik berdiskusi tentang apa yang telah ditampilkan guru. Selanjutnya pada kelas kontrol menggunakan media pembelajaran digital storytelling yang mengandung unsurgambar statis, warna, musik dan teks, kemudian guru menampilkan video digital storytelling, lalu setelah guru menampilkan video tersebut, guru akan bertanya kepada masing-masing anak tentang isi video yang telah ditampilkan guru

\section{Pengaruh Interaksi antara Media Pembelajaran Digital dan Kepercayaan Diri terhadap Hasil Belajar Pendidikan Agama Islam}

Proses belajar mengajar tidak terlepas dari strategi, metode dan media yang digunakan guru. Salah satunya adalah penggunaan media pembelajaran agar mempermudah guru untuk menyampaikan materi pelajaran Pendidikan Agama Islam kepada siswa. Media pembelajaran merupakan suatu teknologi pembawa pesan yang dapat digunakan untuk keperluan pembelajaran dalam menunjang keberhasilan proses belajar mengajar (Rusman, 2017). Media pembelajaran digital adalah komponen pembawa pesan yang berisikan materi pelajaran yang digunakan oleh guru dalam proses pembelajaran 
untuk menunjang keberhasilan proses belajar siswa menjadi efektif dan efisien dengan menggunakan sistem komputer karena proses penyampaian informasinya lebih mudah, cepat dan akurat.

Hermayanti (2015) menyatakan bahwa kepercayaan diri merupakan keyakinan yang bersifat kompleks dan dinamis yang dimiliki seseorang untuk mencapai tujuan yang harapkan.Kepercayaan diri akan memperkuat motivasi mencapai keberhasilan, karena semakin tinggi kepercayaan terhadap kemampuan diri sendiri, semakin kuat pula semangat untuk menyelesaikan pekerjaannya. Kemauannya untuk mencapai apa yang menjadi sasaran tugas juga akan lebih kuat. Berarti dirinya juga mempunyai komitmen kuat untuk bekerja dengan baik, supaya penyelesaian pekerjaannya berjalan dengan sempurna (Hendriana, 2014).

Pada saat pembelajaran, kepercayaan diri siswa dipengaruhi oleh faktor lingkungan sekolah yang salah satunya terlibat guru karena guru memberikan motivasi, dukungan dan penguatan terhadap siswa. Kepercayaan diri siswa sangat dibutuhkan agar keaktifan siswa di kelas akan muncul sehingga suasana kelas akan menjadi kondusif, adanya timbal balik (feedback) antara guru dan siswa, maupun antara siswa dengan siswa yang lainnya sehingga akan berpengaruh pada hasil belajar siswa. Penggunaan media pembelajaran digital yang digunakan oleh guru dalam proses pembelajaran untuk mendukung, memotivasi siswa agar munculnya kepercayaan diri sehingga berpengaruh terhadap hasil belajar siswa. Hasil belajar siswa dapat diketahui melalui evaluasi yang dilakukan guru.Hasil belajar siswa tidak saja diukur dari tingkat penguasaan ilmu pengetahuan, tetapi juga sikap dan keterampilan.Penilaian hasil belajar siswa mencakup segala hal yang telah dipelajari di sekolah, berkaitan dengan pengetahuan, sikap dan keterampilan yang berkaitan dengan mata pelajaran Pendidikan Agama Islam yang dipelajari siswa.

\section{Perbedaan Hasil Belajar Pendidikan Agama Islam Antara Anak Yang Diberikan Media Pembelajaran Digital Animasi Dan Yang Diberikan Media Pembelajaran Digital Storytelling Pada Anak Yang Memiliki Kepercayaan Diri Tinggi}

Usaha untuk mendapatkan hasil belajar yang baik, siswa harus mengerti materi apa yang disampaikan oleh guru. Guru dapat memakai media pembelajaran dalam proses pembelajaran agar siswa tertarik dan memudahkan siswa agar lebih paham terhadap materi yang disampaikan guru. Pelajaran yang dibuat ke visualisasi ke dalam bentuk gambar animasi lebih bermakna dan menarik, lebih mudah diterima, dipahami, lebih dapat memotivasi (Sukiyasa \& Sukoco, 2013). Selanjutnya, hasil belajar siswa menggunakan pembelajaran kooperatif yang diintegrasikan dengan media animasi komputer lebih baik secara signifikan (Irham, 2018).

Media pembelajaran Digital Storytelling juga dapat meningkatkan hasil belajar siswa dan terbukti efektif menunjang proses pembelajaran siswa (Prananta et al., 2017). Media pembelajaran Digital Storytelling dapat meningkatkan motivasi siswa secara efektif, kompetensi masalah dan pencapaian hasil belajar (Hung et al., 2012). Hasil belajar siswa dapat diukur dari cognitive (pengetahuan), affective (sikap) dan pshycomotor (keterampilan). Kepercayaan diri akan mempengaruhi semua aspek kehidupan siswa di antaranya adalah di lingkungan sekolah ketika pembelajaran berlangsung. Siswa yang mempunyai kepercayaan diri akan dapat menyelesaikan tugasnya sesuai tahapan perkembangannya dengan baik. Kepercayaan diri merupakan dasar dari motivasi diri siswa untuk berhasil meningkatkan hasil belajar.

Penggunaan media pembelajaran digital animasi dan media pembelajaran digital storytelling dapat membangkitkan motivasi, daya kreativitas dan semangat belajar siswa agar mencapai hasil belajar yang memuaskan. Media pembelajaran digital animasi dan media pembelajaran digital storytelling memudahkan guru dalam menyampaikan materimata Pelajaran Agama Islam sehingga anak akan lebih cepat mengerti dan mudah menarik minat anak-anak. Media pembelajaran digital animasi mengandung unsur gambar yang dinamis, warna, musik dan teks sehingga membuat anak menjadi tertarik, termotivasi dan semangat dalam belajar. Dengan adanya minat, ketertarikan, motivasi dan semangat belajar pada siswa dengan menggunakan media pembelajaran digital animasi akan membuat siswa menjadi percaya diri dalam menjawab soal-soal sehingga mempengaruhi hasil belajar anak dalam mata 
Kepercayaan diri akan mempengaruhi semua aspek kehidupan siswa di antaranya adalah di lingkungan sekolah ketika pembelajaran berlangsung. Siswa yang mempunyai kepercayaan diri akan dapat menyelesaikan tugasnya sesuai tahapan perkembangannya dengan baik. Kepercayaan diri merupakan dasar dari motivasi diri siswa untuk berhasil meningkatkan hasil belajar.Penelitian yang dilakukan Nurani et al.(2018) menyatakan bahwa terdapat pengaruh signifikan antara kepercayaan diri terhadap prestasi hasil belajar. Oleh karena itu, siswa yang memiliki rasa kepercayaan diri tinggi akan memperoleh hasil yang baik. Sedangkan siswa yang kurang percaya diri dalam mengerjakan tugas menyebabkan prestasi belajar siswa pada akhirnya tidak sesuai yang diharapkan (Situmorang, 2018).

Siswa yang kepercayaan dirinya tinggi akan senang ketika mendapatkan tugas yang menantang, selalu berpikir positif, berani mengungkapkan pendapat, berani mengambil resiko, pandai berkomunikasi serta bersikap optimis dengan kemampuan yang dimilikinya. Kepercayaan diri yang dimiliki siswa membuat keyakinan terhadap dirinya sendiri bahwa dirinya dapat menyelesaikan tugas tertentu sampai selesai dan mendapat hasil yang baik. Kepercayaan diri yang dimiliki siswa membuat siswa meyakini kemampuannya untuk dapat mempelajari mata pelajaran Pendidikan Agama Islam sehingga anak mendapat hasil belajar Pendidikan Agama Islam yang baik.

\section{Perbedaan Hasil Belajar Pendidikan Agama Islam Antara Anak Yang Diberikan Media Pembelajaran Digital Animasi Dan Yang Diberikan Media Pembelajaran Digital Storytelling Pada Anak Yang Memiliki Kepercayaan Diri Rendah}

Hasil belajar Pendidikan Agama Islam adalah proses perubahan tingkah laku pada siswa agar siswa meyakini, memahami dan mengamalkan ketentuan-ketentuan ajaran Agama Islam yang dapat diukur melalui pengetahuan (cognitive), sikap (affective) dan keterampilan (psychomotor). Usaha untuk mencapai hasil belajar Pendidikan Agama Islam yang baik, harus adanya kepercayaan diri dalam diri siswa karena dengan adanya kepercayaan diri siswa yakin terhadap dirinya sendiri dapat menjawab soal-soal yang diberikan guru. Kepercayaan diri merupakan dasar dari motivasi diri siswa untuk berhasil meningkatkan hasil belajar. Siswa yang kepercayaan dirinya rendah akan merasa takut untuk mengungkapkan pendapat, takut dengan kegagalan, bersikap pesimis dengan kemampuannya, tidak pandai berkomunikasi karena tidak pandai bersosialisasi dan lebih suka dengan tugas yang tantangannya sedikit. Siswa yang sulit mengembangkan kepercayaan dirinya akan berakibat terganggunya pencapaian dalam hasil belajar.

Guru dapat memakai media pembelajaran dalam proses pembelajaran agar siswa tertarik dan memudahkan siswa agar lebih paham terhadap materi yang disampaikan guru sehingga anak dapat menjawab soal-soal dengan baik yang diberikan guru. Media pembelajaran merupakan suatu teknologi pembawa pesan yang dapat digunakan untuk keperluan pembelajaran; media pembelajaran merupakan sarana fisik untuk menyampaikan materi pelajaran (Rusman, 2017). Media pembelajaran digunakan oleh guru dalam proses pembelajaran dapat menunjang keberhasilan proses belajar siswa. Media pembelajaran digital animasi lebih membuat anak tertarik karena mengandung unsur gambar yang dinamis, warna, musik dan teks yang memudahkan anak untuk mengingat sehingga dapat menjawab soal-soal serta memberikan perubahan pada hasil belajar Pendidikan Agama Islam. Sedangkan media pembelajaran Digital Storytelling yang mengandung unsur gambar yang statis, warna, musik dan suara membuat anak lebih dominan sebagai pendengar yang aktif karena gambar dalam media pembelajaran Digital Storytelling tidak bergerak seperti animasi.

Dari penjelasan di atas, maka ada perbedaan hasil belajar Pendidikan Agama Islam kelas 2 SD dengan menggunakan media pembelajaran digital animasi dan media pembelajaran Digital Storytelling dengan anak yang mempunyai kepercayaan diri rendah.

\section{SIMPULAN}

Berdasarkan hasil penelitian, maka dapat diambil kesimpulan bahwa secara keseluruhan hasil belajar Pendidikan Agama Islam kelompok anak yang menggunakan media pembelajaran digital animasi lebih tinggi dibandingkan dengan kelompok anak yang menggunakan media pembelajaran digital storytelling. Hal ini disebabkan media pembelajaran digital animasi dapat menarik minat siswa dan membuat siswa lebih cepat mengerti. Penggunaan media pembelajaran digital animasi ini menjadikan pembelajaran aktif, kreatif, efektif dan menyenangkan. 


\section{UCAPAN TERIMAKASIH}

Peneliti mengucapkan terima kasih sedalam-dalamnya kepada Allah SWT atas limpahan karunia dan hidayahnya sehingga penulis dapat melaksanakan penelitian dan menyelesaikan karya ilmiah ini. Dosen pembimbing saya yang telah memberikan arahan dan masukan selama penyusunan karya ilmiah, orang tua saya yang telah memberikan doa dan mendukung saya, pihak sekolah khususnya Sekolah Dasar Negeri 064037 di Kelurahan Bandar Selamat berjumlah 59 anak dan Sekolah Dasar Negeri 060913 Kelurahan Bantan atas kerjasamanya selama penulis melakukan penelitian.

\section{DAFTAR PUSTAKA}

Fua, J. La, \& Dewi Sartiwi. (2015). Meningkatkan Hasil Belajar Pendidikan Agama Islam Melalui Strategi Pembelajaran Questions Students Have Pada Siswa Kelas Viia Smp Negeri 2 Wakorumba Utara Kabupaten Muna. Jurnal Al-Ta'dib, 8(1), 39-60.

Handayani, H., Yetri, \& Putra, F. G. (2018). Pengembangan Media Pembelajaran Berbasis Macromedia Flash. Jurnal Tatsqif: Jurnal Pemikiran Dan Penelitian Pendidikan, 1(2), 87-100. https://doi.org/10.24256/jpmipa.v1i2.95

Heris Hendriana. (2014). Membangun Kepercayaan Diri Siswa Melalui Pembelajaran Matematika Humanis. Jurnal Pengajaran MIPA, 19(April), 52-60. https://doi.org/10.18269/jpmipa.v19i1.424

Hermayanti, T. (2015). Peningkatan Kepercayaan Diri Melalui Kegiatan Menari Kreatif. Jurnal Pendidikan Usia Dini, 9(2), 389-400. https://doi.org/https://doi.org/10.21009/JPUD.092.12

Hung, A. C., Hwang, G., \& Huang, I. (2012). A Project-based Digital Storytelling Approach for Improving Students ' Learning Motivation, Problem-Solving Competence and Learning Achievement. Journal of Educational Technology \& Society, 15(4).

Irham, W. (2018). Peningkatan Hasil Belajar Siswa dengan Pembelajaran Kooperatif dan Talenta Conference Series Peningkatan Hasil Belajar Siswa dengan Pembelajaran Kooperatif dan Penggunaan Media Animasi Komputer. Talenta Conference: Science E Techonology, 2(1), 0-5. https://doi.org/10.32734/st.v2i1.350.

Islahuddin, M. A. (2015). Penggunaan Media Animasi Berbasis Multimedia Untuk Meningkatkan Hasil Belajar Pada Materi Sistem Efi (Electronic Fuel Injection) In The Efi ( Electronic Fuel Injection) System Material ). Jurnal Pendidikan Teknik Mesin, 15(2), 98-102.

Kasan, A. (2018). Upaya Meningkatkan Hasil Belajar Pendidikan Agama Islam ( Pai ) Menggunakan Metode Hypnoteaching Bagi Siswa Kelas Vii C Smpn 1 Limbangan Kabupaten Kendal. Jurnal Studi Dan Penelitian Pendidikan Islam, 1(Februari). https://doi.org/10.30659/jspi.v1i1.2428.

Latif, M., Zukhairina, Zubaidah, R., \& Afandi, M. (2016). Orientasi Baru Pendidikan Anak Usia Dini: Teori dan Aplikasi (3rd ed.; Suwito, ed.). Jakarta: Prenadamedia Group.

Lubis, S. (2017). Hubungan Kecerdasan Emosional Terhadap Prestasi Belajar Siswa Pada Mata Pelajaran Pendidikan Agama Islam. HIKMAH : Jurnal Pendidikan Islam, 6(2), 237-258.

Mahfudzah, F., K, A. H., \& Tanjung, S. (2018). Pengembangan Media Pembelajaran Interaktif Pada Mata Pelajaran Agama Islam Siswa Sd. Jurnal Tik Dalam Pendidikan, 5(2). https://doi.org/10.24114/jtikp.v5i2.12593.

Nurani, Sunarto, \& Wardani, D. K. (2018). Pengaruh Kepercayaan Diri dan Motivasi Berprestasi Terhadap Prestasi Belajar Peserta Didik Pada Mata Pelajaran Ekonomi di SMA Negeri 8 Surakarta. BISE: Jurnal Pendidikan Bisnis Dan Ekonomi, 4(1), 1-13. https://doi.org/http:/ / dx.doi.org/10 .20961/bise.v4i1.20 028

Prananta, Y. R., Setyosari, P., \& Santoso, A. (2017). Pengembangan Media Boneka Tangan. Jurnal Pendidikan: Teori, Penelitian Dan Pengembangan, 2(Mei), 627-636.

Rusman. (2017). Belajar dan Pembelajaran Berorientasi Standar Proses Pendidikan (1st ed.; Suwito, ed.). Jakarta: Kencana.

Situmorang, P. L. (2018). Pengaruh Penerapan Pembelajaran Kooperatif Tipe Teams Hubungan Resiliensi Diri Dan Efikasi Diri Dengan Prestasi Belajar Ekonomi Siswa Kelas Xi Ips Sma Negeri 3 Medan. Prosiding Seminar Nasional SINASTEKMAPAN, I(November), 1178-1186.

Sukiyasa, K., \& Sukoco. (2013). Pengaruh Media Animasi Terhadap Hasil Belajar Dan Motivasi Belajar Siswa Materi Sistem Kelistrikan Otomotif. Jurnal Pendidikan Vokasi, 3(Februari), 126-137. https://doi.org/10.21831/jpv.v3i1.1588.

Tohirin. (2005). Psikologi Pembelajaran Pendidikan Agama Islam (1st Ed.). Jakarta: PT Rajagrafindo Persada. 